УДК 631.145

S. Khalatur,

Doctor of Economic Sciences, associate professor, Professor of Finance,

Banking and Insurance Department, Dnipro State Agrarian and Economic University

ORCID ID: 0000-0001-8331-3341

O. Dubovych,

PbD in Law, Associate Professor of Entrepreneurship and Law Department

Poltava State Agrarian Academy

ORCID ID: 0000-0003-3390-1393

A. Puss,

student of gr. MGFBSz-1-18, Dnipro State Agrarian and Economic University

ORCID ID: 0000-0002-4414-6517

DOI: $10.32702 / 2306-6814.2019 .24 .84$ *

\title{
COMPLEX ASSESSMENT
}

\section{OF FINANCIAL AND ECONOMIC} CONDITION OF THE ENTERPRISES OF AGRICULTURAL INDUSTRY

\author{
С. М. Халатур, \\ А. е. н., доцент, професор кафедри фінансів, банківської справи та страхування, \\ Аніпровський державний аграрно-економічний університет \\ О. В. Аубович, \\ к. ю. н., доцент кафедри підприємництва і права, Полтавська державна аграрна академія, \\ А. В. Пусс, \\ студентка гр. МгФБСз-1-18, Аніпровський державний аграрно-економічний університет
}

\section{КОМП ЕКСНА ОЦІНКА ФІНАНСОВО-ЕКОНОМІЧНОГО СТАНУ ПІАПРИЕМСТВ} СІАЬСЬКОГОСПОААРСЬКОЇ ГА АУЗІ

The peculiarities of financial state estimation of the enterprises of the agricultural industry are highlighted. The purpose of the article was to reveal the peculiarities of financial condition diagnostics and to determine the indicators that characterize it in agricultural enterprises. The analysis showed that agriculture has the strong potential to become the most profitable and competitive industry.

The main tasks of financial activity analysis of agrarian enterprise are determined. It is substantiated that the financial condition of an agricultural enterprise cannot be sustainable if it does not receive profit in the amount that provides the necessary increase of financial resources aimed at strengthening the material and technical base of the enterprise and their social sphere. Since financial status is one of the most important characteristics of the activity of each enterprise, it should be systematically and comprehensively evaluated using different methods, techniques and methods of analysis. This will make it possible to critically evaluate the financial results of the enterprise activity both in statics for a certain period and in dynamics - for a number of periods, will allow determining ways of financial resources usage efficiency, their rational allocation.

The concept of financial management includes basically all financial decisions in all functional areas of the enterprise. The analysis of the financial position of enterprises is based mainly on relative indicators, since absolute indicators of the balance in the conditions of inflation are almost impossible to make in a comparable form. The financial status of an agricultural enterprise is determined by the following elements: profitability of the enterprise; optimality of distribution of the profit which remains at the disposal of the enterprise after payment of taxes and obligatory payments; the availability of 
own financial resources not only the minimum required level for the organization of the production process and the process of sales; rational placement of fixed and circulating assets; solvency and liquidity.

It is argued that it is necessary to provide a system of financial monitoring of each of the components of the financial condition of agricultural enterprises, which would be able to optimize it according to the prospects of development.

Висвітлено особливості оцінки фінансового стану підприємств сільськогосподарської галузі. Метою статті стало розкриття особливостей діагностики фінансового стану та визначення показників, що його характеризують на сільськогосподарських підприємствах. Аналіз показав, що сільське господарство має потужний потенціал стати найбільш дохідною і конкурентоспроможною галуззю.

Визначено основні завдання аналізу фінансової діяльності аграрного підприємства. Обгрунтовано, що фінансовий стан сільськогосподарського підприємства не може бути стійким, якщо воно не отримує прибутку у розмірах, що забезпечують необхідний приріст фінансових ресурсів, спрямованих на зміцнення матеріально-технічної бази підприємства та їх соціальної сфери. Оскільки наявний фінансовий стан - це одна з найважливіших характеристик діяльності кожного підприємства, то його треба систематично і всебічно оцінювати з використанням різних методів, прийомів та методик аналізу. Це уможливить критичну оцінку фінансових результатів діяльності підприємства як у статиці за певний період, так і в динаміці - за низку періодів, дасть змогу визначити способи ефективності використання фінансових ресурсів, їх раціонального розміщення.

Концепція управління фінансовим станом включає в себе в основному всі фінансові рішення в усіх функціональних сферах підприємства. Аналіз фінансового стану підприємств грунтується головним чином на відносних показниках, оскільки абсолютні показники балансу в умовах інфляції практично неможливо привести в зіставний вигляд. Фінансовий стан сільськогосподарського підприємства визначають за такими елементами: прибутковістю роботи підприємства; оптимальністю розподілу прибутку, що залишився у розпорядженні підприємства після сплати податків і обов'язкових платежів; наявністю власних фінансових ресурсів не лише мінімально потрібного рівня для організації виробничого процесу і процесу реалізації продукції; раціональним розміщенням основних і обігових фондів; платоспроможністю та ліквідністю.

Стверджується, що необхідно забезпечити систему фінансового моніторингу кожної із складових фінансового стану сільськогосподарських підприємств, яка змогла б надати можливість оптимізувати їі відповідно до перспектив розвитку.

Key words: financial status, profitability, liquidity, property condition, financial stability, business activity.

Ключові слова: фінансовий стан підприємстВа, прибутковість, лікВідність, майновий стан, фрінансова стійкість, ділова активність.

\section{INTRODUCTION}

The relevance of this topic is due to the need for a systematic assessment of the financial status of agricultural enterprises using a system of indicators to

Table 1. Dynamics of gross agricultural production of Ukraine

\begin{tabular}{|l|l|l|l|l|l|l|}
\hline \multicolumn{1}{|c|}{ Indicator } & 2013 & 2014 & 2015 & 2016 & 2017 & $\begin{array}{c}2017 \\
\text { in \% to } \\
2013\end{array}$ \\
\hline GDP, billion UAH & 1454,9 & 1566,7 & 1979,5 & 2383,2 & 2982,9 & 205,0 \\
\hline including Agriculture & 119,6 & 122,2 & 166,3 & 200,2 & 360,9 & 301,8 \\
\hline Share of agriculture, \% & 9,1 & 10,2 & 11,4 & 12,9 & 12,1 & $+3,0$ в.П. \\
\hline $\begin{array}{l}\text { Production index of } \\
\text { gross output of } \\
\begin{array}{l}\text { agricultural } \\
\text { products, } \%\end{array}\end{array} 111,3$ & 102,2 & 95,2 & 114,6 & 112,1 & $+0,8$ в.П. \\
\hline
\end{tabular}

Source: calculated according to the State Statistics Service of Ukraine. determine the level of development of the enterprise, its financial stability, independence, liquidity, solvency, and business activity, its place in the national market and in the agro-industrial complex of the state.

Agriculture in Ukraine is one of the priority sectors of the economy. Agricultural enterprises have lost their sustainability, their ability to maintain optimal proportionality in the development of their production, to adapt to changing environmental conditions. All this requires the introduction of an appropriate system of improving the financial and economic sustainability of enterprises as the most important component of ensuring their competitiveness in the process of achieving strategic development goals. The analysis of the financial condition of an agricultural enterprise is an integral part of the agro-industrial complex. It is from the analysis and diagnosis of the economic condition of 
Table 2. The profitability level of the main types of economic activity of enterprises of the national economy in Ukraine,\%

\begin{tabular}{|c|c|c|c|c|c|c|c|}
\hline Activity & $2000 \mathrm{p}$. & 2010 p. & 2011 p. & 2013 p. & 2016 p. & 2017 p. & $\begin{array}{c}2017 \\
\text { in } \\
\% \text { to } \\
2000\end{array}$ \\
\hline \multicolumn{8}{|c|}{ Operational activity: } \\
\hline National economy & 2,7 & 3,9 & 3,3 & 5,8 & 6,3 & 6,2 & $+3,5$ \\
\hline industry & 3,4 & 2,9 & 1,8 & 6,0 & 7,2 & 7,4 & +4 \\
\hline construction & 7,3 & 2,1 & $-0,9$ & $-0,3$ & 2,4 & 2,2 & $-5,1$ \\
\hline financial activity & 4,9 & 2,4 & 1,5 & 2,0 & 2,3 & 2,4 & $-2,5$ \\
\hline Agriculture & $-1,6$ & 12,9 & 14,7 & 23,2 & 29,6 & 29,4 & +31 \\
\hline \multicolumn{8}{|c|}{ Production in the agricultural enterprises - } \\
\hline total & $-1,0$ & 13,4 & 13,8 & 27,0 & 32,7 & 32,4 & $+33,4$ \\
\hline $\begin{array}{l}\text { including: crop } \\
\text { production }\end{array}$ & 30,8 & 19,6 & 16,9 & 32,3 & 40,2 & 40,6 & $+9,8$ \\
\hline animal husbandry & $-33,8$ & 0,1 & 5,5 & 13,0 & 11,7 & 12,1 & $+45,9$ \\
\hline
\end{tabular}

Source: calculated according to the State Statistics Service of Ukraine.

the enterprise that the success of its activity depends, which is why so much attention is paid to the issues of analysis and assessment of the financial condition of agricultural enterprises.

Based on the analysis and evaluation of the performance, a development strategy can be developed that will not only control the future of the enterprise, but also make it more predictable and successful.

\section{ANALYSIS OF RECENT RESEARCH AND PUBLICATIONS}

Investigation of issues related to determining the nature of the financial condition of the enterprise, as well as the method of its evaluation are devoted to the works of domestic and foreign scientists, in particular such as O.Ya. Basilinskaya, M.D. Bilyk, I.O. Blank, K.V. Izmailova, V.V. Kovalev, M.Ya. Korobov, R.O. Kostirko, G.O. Kramarenko, L.A. Lakhtionova, A.M. Poddyrogin, G.V. Savitskaya, P.C. Saifulin, O.M. Tereshchenko, Yu.S. Tsal-Tsalko, O.E. Chorna, V.V. Sheremet. Despite this, the lack of a single methodology for assessing financial condition leads to the use of a large variety of indicators, often without some systematization, as well as a clear algorithm for calculating, complicate the implementation of financial condition assessment in the practical activity of enterprises.

\section{FORMULATING THE GOALS OF THE ARTICLE}

The purpose of the article is to reveal the peculiarities of financial condition diagnostics and to determine the indicators that characterize it in agricultural enterprises.

\section{RESULTS OF THE RESEARCH}

The share of agriculture in the GDP of Ukraine is $12 \%$. Increasing agricultural production is potentially possible if the resources, land, financial, labor, information, etc. are sufficiently and effectively used. The dynamics of gross agricultural production of Ukraine is analyzed in Table 1.

The analysis of Table 1 shows that the GDP of Ukraine doubled in the period under review, and agriculture three times. The share of agriculture in Ukraine's GDP has tripled, which is a positive trend. The index of output of gross agricultural production for 2013-2017 is increased by $0.8 \mathrm{pp}$, which is a positive trend.

Agricultural production is quite profitable compared to other sectors of the national economy of Ukraine. In 2000-2017, the profitability of operating activities in the national economy was $2.7-6.2 \%$, while in agriculture $1.6-29.4 \%$. During the studied period, there is a tendency of increase of level of profitability of agriculture in comparison with other branches of economy of Ukraine (Table 2).

Table 3. Economic results of activity of agricultural enterprises in Ukraine

\begin{tabular}{|l|l|l|l|l|l|l|l|}
\hline \multicolumn{1}{|c|}{ Indexes } & 2012 & 2013 & 2014 & 2015 & 2016 & 2017 & $\begin{array}{c}2017 \\
\text { in } \% \text { to } \\
2012\end{array}$ \\
\hline $\begin{array}{l}\text { Number of enterprises, } \\
\text { units }\end{array}$ & 42595 & 402307 & 45910 & 42949 & 44744 & 44925 & 105,47 \\
\hline $\begin{array}{l}\text { Number of employees } \\
\text { employed in agricultura } \\
\text { industry production, } \\
\text { persons }\end{array}$ & 582106 & 558566 & 552192 & 503387 & 522473 & 529674 & 90,99 \\
\hline $\begin{array}{l}\text { Area of agricultural } \\
\text { land, thousand ha }\end{array}$ & 21107,4 & 21232,5 & 21631,9 & 21009,6 & 21378,1 & 21390,6 & 101,34 \\
\hline $\begin{array}{l}\text { Profit from the sale of } \\
\text { agricultural products, } \\
\text { mln. UAH }\end{array}$ & 21833,3 & 22683,3 & 14294,1 & 38289,1 & 42872,1 & 43569,4 & 199,55 \\
\hline $\begin{array}{l}\text { Profitability level - } \\
\text { total,\% }\end{array}$ & 26,5 & 20,7 & 25,8 & 45,6 & 32,7 & 34,6 & $+8,1 \mathrm{pp}$ \\
\hline including plant growing & 27,2 & 21,0 & 29,2 & 50,6 & 40,2 & 42,1 & $+14,9 \mathrm{pp}$ \\
\hline animal husbandry & 8,4 & 9,5 & 13,4 & 22,1 & 11,7 & 12,3 & $+3,9 \mathrm{pp}$ \\
\hline
\end{tabular}

Source: calculated according to the State Statistics Service of Ukraine. 
Analysis of Table 2 shows that agriculture has the strong potential to become the most profitable and competitive industry. Table 3 analyzes the economic performance of Ukrainian agricultural enterprises. The analysis shows that in 2017 the profit from the sale of agricultural products amounted to UAH 43569,4 million, which is almost twice as much as in 2012. The level of profitability of agricultural activity during the period under review is also increasing.

Positive trends with efficient use of land resources will contribute to the economic growth of agricultural enterprises and increase the volume of production and sale of agricultural products. However, despite the positive performance of agricultural enterprises, the structure and condition of land resources is of concern.

The analysis of the financial position of enterprises is based mainly on relative indicators, since absolute indicators of the balance in the conditions of inflation are almost impossible to make in a comparable form. The financial status of an agricultural enterprise is determined by the following elements: profitability of the enterprise; optimality of distribution of the profit which remains at the disposal of the enterprise after payment of taxes and obligatory payments; the availability of own financial resources not only the minimum required level for the organization of the production process and the process of sales; rational placement of fixed and circulating assets; solvency and liquidity.

Assessment of financial position allows you to identify and characterize:

- efficiency of financial and economic activity of the enterprise as a whole, as well as efficiency of use of financial resources in particular;

- the level of creditworthiness of the enterprise as a borrower of financial resources for carrying out business activities;

- the level of entrepreneurial risk regarding the ability to pay off liabilities, the ability to build up assets, attract investments;

- the main priorities of quality planning, forecasting, budgeting;

- the policy of distribution and use of profit for the needs of the entity;

- the reasons for the corresponding changes, as well as tendencies and priority directions of the enterprise development according to the indicators of its financial condition.

Corporate finance management covers all functional areas within the business from marketrelated issues to operational issues in production. And both, marketing issues and operational issues regularly require financial resources, investments that in turn need financing. Concern about the effectiveness of investment and financial decisions is the area of financial managers.

Financial decisions are inherently economic decisions, although executives may use different information systems to account for information resources. A number of external factors in the business environment affect the decisions of managers and businesses: for example, financial markets, government rules and regulations, tax structure, competitors, general business conditions, the global economy, and more. Management should take these factors into account when deciding, for example, the types of goods or services offered, marketing and production systems, investment policies, the amount of credit used, dividend policy, working capital and more. The results of these decisions are subsequently filtered, transformed and presented in the entity's financial statements; and financial statements, in turn, are an important aspect of financial decision-making among users of these statements.

The concept of financial management includes basically all financial decisions in all functional areas of the enterprise. Financial decisions typically relate to the acquisition, management, and financing of resources that generate cash flows and affect a company's wealth. In general, regardless of whether they are purchasing, managing or financing decisions, they vary from active to passive. The idea is to get the best long-term benefits from distributing limited enterprise resources. In this sense, decisions are made in advance. At the same time, decisions, plans and policies must be followed; so in this sense, decisions are more historically oriented.

To sum up, the idea is to ensure that the financial goals of the enterprise are fulfilled at all times. Therefore, the assessment of the financial condition of an agricultural enterprise is based mainly on two elements: the concepts of economy and the information system of accounting.

Financial decisions are often made through organizational initiatives. The value management approach and other initiatives to improve the organization extend to a wide range of theoretical constructs and practices. In particular, the value model, the balanced scorecard, activity-based costing, cash flow and return on investment. Each of these approaches can be seen as examples of initiatives to improve the organization of the financial position of the enterprise, each of its specific framework and focus, but they are all aimed at improving the efficiency of the enterprise. Different frameworks should not be regarded as mutually exclusive methods; in practice, they are of ten complementary because of their focus.

If businesses do not follow the changes that span the entire modern world, they will collapse and go bankrupt. The effective operation of an enterprise depends on many factors, one of the most important being its financial potential. In today's business environment, it is important to take into account such elements of financial potential management as solvency, financial stability and business activity, which is determined, in particular, by working capital efficiency, profitability of the enterprise, such as the potential of formation and completeness of use of financial resources, balancing of cash flows and the level of financial risk. The efficiency of using resources and increasing the level of economic sustainability of an enterprise in the current economic conditions largely depends on the availability, use and improvement of the financial potential of the enterprise.

The areas of managerial influence on strengthening the financial condition of the enterprise are presented in Fig. 1.

The primary step in improving the financial condition of Ukrainian agricultural enterprises is to find the optimal balance between equity and debt, which would ensure 


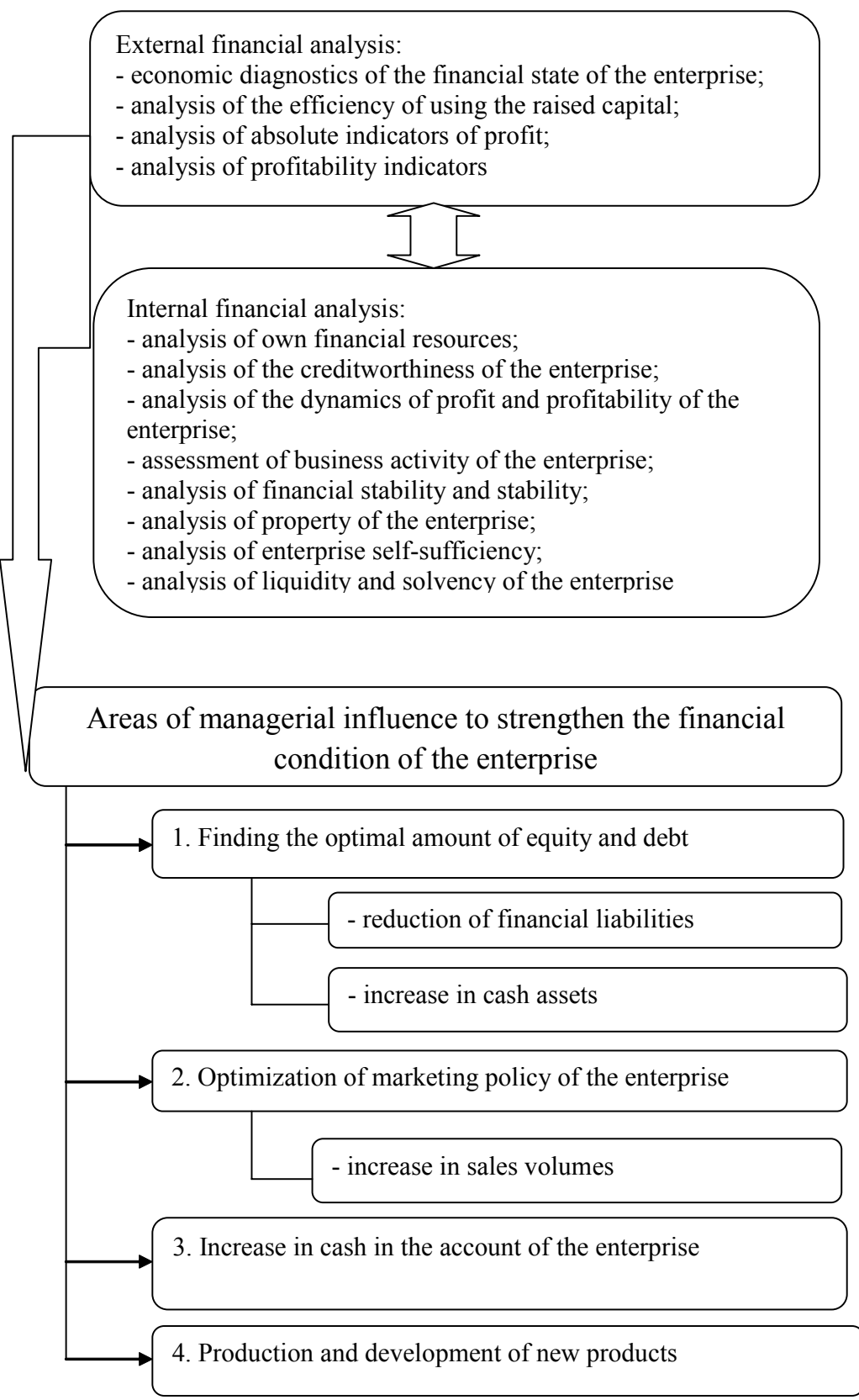

Fig. 1. The areas of managerial influence on strengthening the financial condition of the enterprise

Source: authors' own development.

minimal financial risk with maximum return on equity. Optimization of the liquidity of the enterprise is realized with the help of an operational mechanism of financial stabilization - a system of measures aimed, on the one hand, at reducing financial liabilities and, on the other, at increasing the monetary assets that provide these obligations.

In a competitive environment, the optimization of the company's sales policy becomes relevant. The company needs to step up its marketing policies in order to promote its products, which, in fact, at the expense of high quality and lower than the industry average, is competitive. Important to solve are the issues of advertising, packaging, production of high-quality souvenir products, branded trade, sales promotion in different ways. The right approach to the promotion of the products of the producers of goods will allow increasing the sales of products, which will create real prerequisites for entering the agricultural enterprise to a stable level of profitability.

Competitiveness in the market can be achieved by reducing the cost of production, through the introduction of new technology, technologies, rational use of both material and labor resources, reducing the proportion of fixed costs in the cost of production, because reducing the cost of production directly proportional to the profit of the enterprise.

Another way to improve the financial condition of an agricultural enterprise is to increase cash in the account of the enterprise, which will increase the absolute liquidity ratio and allow the enterprise to take long and short-term loans to the bank to finance current activities, which are issued only to solvent enterprises in which the coefficient is absolute the norm. The increase in funds can be ensured by the sale of excess production and non-productive funds, letting them. Another direction of improving the financial condition of an agricultural enterprise may be the 
production and development of new products that will interest consumers, as well as obtaining licenses for the production of "running" goods, which will help to stabilize and improve the financial condition of the enterprise.

The financial condition of an agricultural enterprise cannot be sustainable unless it receives a profit in the amount that provides the required increase in financial resources aimed at strengthening the material and technical base of the enterprise and their social sphere. Since financial status is one of the most important characteristics of the activity of each enterprise, it should be systematically and comprehensively evaluated using different methods, techniques and methods of analysis. This will make it possible to critically evaluate the financial results of the enterprise activity both in statics for a certain period and in dynamics - for a number of periods, will allow determining ways of efficiency of use of financial resources, their rational allocation.

It is necessary to provide a system of financial monitoring of each of the components of the financial condition of agricultural enterprises, which would be able to optimize it according to the prospects of development. So, if the monitoring revealed insufficient level of financial stability of the enterprise, then the following actions can be implemented:

- optimization of movement of financial resources of the enterprise and regulation of financial relations that arise in the course of settlement relations between economic entities in order to effectively distribute them;

- development of sustainable financial strategy of the enterprise;

- development of projects of perspective and current financial plans, forecast balance sheets and budgetary funds;

- calculation of projected values of sales (production plans) and investment plans, production costs, etc.;

- identification of sources of financing of economic activity, as well as budget financing, long and short-term crediting, etc.;

- coordination of financial units of the enterprise.

It is at the expense of a stable financial component that an agricultural enterprise is able to invest in the development of new goods (services), to develop new markets, to provide or promote the marketing stability of the enterprise, to develop new lines of activity, to maintain investment sustainability, and, having highly qualified staff, enterprises, and effective management process.

It can be concluded that the achievement of financial sustainability of an agricultural enterprise is possible only if the elements of modern financial management, timely response to changes in the environment and strategic vision of the future state of the enterprise are used. Improvement of financial work in an agricultural enterprise should be carried out in the following areas:

- systematic and continuous financial analysis of their activities;

- organization of circulating assets in accordance with existing requirements in order to optimize the financial condition; introduction of management accounting and on this basis optimization of expenses of the enterprise;
- optimizing the distribution of revenue and choosing the most effective dividend policy;

- wider introduction of commercial credit in order to optimize sources of funds, etc.

There are hypotheses on the structure of efficient agricultural production.

It is assumed that small-sized agricultural enterprises will prefer to use retained earnings to finance their investments, and these enterprises rely on retained earnings to finance investment opportunities, since this is the cheapest form of financing. Although many small farms do not have credits in their capital structure, it can of ten happen when the internally generated returns are insufficient to meet their investment needs. Therefore, profit is negatively related to debt financing at some point.

According to static trade-off theory, a profitable firm expects that debt levels will be higher to offset corporate taxes; however, we do not expect this to be the case in the case of small businesses, since the profits of small businesses are less profitable than the large profits of a corporation and therefore face lower taxes than large firms. For this reason, the incentives for small firms to have tax protection arrears are not as great as those for large firms. However, it is noted that non-tax tax shields such as depreciation and investment tax credits are important to the observed capital structures of small businesses.

$\mathrm{H}$ 1: There is a negative correlation between profitability and financial leverage. An important factor influencing the demand and supply of finance for small and medium-sized businesses is the level of information asymmetry that is closely linked to industry. Often characterized as relatively opaque in nature, small businesses are ultimately associated with a higher level of information asymmetry than larger firms. According to static trade theory, firms adjust to the target capital structures, of ten measured as industry averages. The debt ratio varies depending on the risk of the assets, the type of assets and the need for external funds. In addition, smaller, less successful firms are more sensitive to the decision to fund larger successful partners in the industry.

$\mathrm{H} 2$ : Branches of agriculture with large tangible assets that are positively related to the level of debt financing. The growth opportunities of small firms with high development potential are likely to have significantly greater growth opportunities relative to their firm's assets. In addition, small, high-tech firms often issue stocks due to low debt levels. Conversely, large firms are much less constrained in their debt to small firms. As a result, when domestic funds are exhausted, the use of external capital for debt financing does not contradict their development strategy.

It can be concluded that the growth of the smallest firms is constrained by the availability of internal finance and, with the increase in debt financing, the likelihood of financial distress increases for the firms most affected by the asymmetry of information, that is, for small firms in most cases. It is also important to note that firms also favor financial instability and often do not want to limit themselves in future investments; so many firms do not take loans to the level of their debt capabilities. For this reason, the presence of growth opportunities can have a significant impact on the actual debt ratio, which means 
that high-performing firms with significant growth opportunities often refuse to make positive investments in projects with a net profit value. Particularly significant future growth opportunities are often considered risky, especially if there is little opportunity for small and mediumsized businesses to use tangible assets as a guarantee that debt will be negatively linked to future growth. However, for small and medium-sized businesses, which rely mainly on debt financing and have little access to other formal sources of external financing, which is the basis for most external financing needs of small agricultural enterprises. It can also be positively related to the level of debt financing depending on the limit of their debt capacity.

$\mathrm{H} 3$ : A positive correlation between the level of growth opportunities and the level of expected compliance with debt financing. As already stated, information asymmetry is considered greater for smaller and younger firms. Younger firms are less likely to have a well-established reputation and experience in making financial payments to creditors, at which potential information asymmetries are diminished. Thus, it is likely that as the company ages, information asymmetries decrease, and there is expected to be a positive relationship between age and leverage to be observed. In addition, as firms' age, they accumulate more retained earnings and rely less on external debt financing and other accumulated internal resources. As with older firms, they are expected to accumulate higher levels of earnings, while younger firms will rely more on debt financing, and especially short-term debt financing. The age is expected to be negatively correlated with the debt ratio.

$\mathrm{H} 4$ : Negative relationship between age and level Risk of debt financing. More risky firms may try to reduce the volatility of their profits by reducing their debt levels; in addition, small and medium-sized enterprises that are considered risky banks may find it more difficult to access debt financing, including long-term debt financing.

$\mathrm{H}$ 5: A negative relationship is expected between risk and financial leverage. Tax shields without debt. Many firms can have significant tax protections in addition to paying off interest. These may include depreciation and investment tax credits. Increasing tax shields reduces the optimal level of debt; however, empirically the results can of ten suggest the opposite. It can be assumed that tangible assets that generate tax shields can also be used to provide additional debt with empirical ambiguity. In this study, tax shields are measured as the ratio of depreciation to assets.

Therefore, a systematic approach to the analysis of the financial condition of an agricultural enterprise involves considering the enterprise as a complex, multi-level and interconnected system, characterized by a number of specific principles, which include:

- integrity - the enterprise as a complete system has a number of properties that qualitatively exceed the sum of the properties of the individual components that create the system;

- structural - the dynamics of enterprise development is largely determined not by the properties of its individual structural components, but, above all, by the properties of its structure, by how the elements are located and interact in the system;
- interdependence of the system and the environment - the enterprise as a system is separated from the environment, formed and manifests its properties in interaction with the environment in which it functions;

- autonomy - the enterprise as a system exists and develops according to not only the general but also its own, but its inherent law;

- adaptability - the enterprise as a system has a certain ability to adapt to changes in the environment, to adapt to new conditions; in fact, the development of the system is a process of adaptation to the changing conditions of the external and internal environment;

- hierarchy - the interaction of elements of the system can be represented in the form of a hierarchy of connections, and the nature and features of the connections of the elements of the system have no less important system-forming value than the elements themselves; each component of the system, in turn, can be represented as a hierarchical system and the system itself as a component of the largest system;

- uniqueness - in every large and complex system, such as an enterprise, there is always a unique character of some properties, qualities, elements; uniqueness is peculiar to both systems and features of their functioning;

- multiplicity of descriptions - because of the fundamental complexity of each system of its knowledge requires comprehensive consideration, construction of many different models, each of which describes only a specific side of the system; development of a single, fully adequate model is impossible, all predictions of systems behavior are probabilistic.

Thus, in order to fulfill the systematic requirements in assessing the financial condition of an enterprise, it is necessary to evaluate not only the individual coefficients, but also their ratios, structure, which will allow summarizing and reflecting in the combined indicator the multiple relationships of the financial indicators of the enterprise. Adhering to the principles of the systematic approach, it is necessary to proceed to use for analysis not the individual coefficients, but their combinations, for which the coefficients should be combined into blocks according to their economic content. Based on the principle of hierarchy, it is possible to combine block assessments into a comprehensive system of comprehensive assessment of the financial condition of the enterprise. From the point of view of the principle of integrity, there is reason to believe that a generalized indicator will give an estimate that qualitatively exceeds the sum of the coefficients included in this block.

\section{CONCLUSIONS AND PROSPECTS FOR FURTHER RESEARCH}

Modern business conditions require agricultural enterprises to respond promptly to changes in the external and, therefore, internal environment, which directly affect the profitability of doing business and are caused by a number of factors. Among them are those that do not depend on the activity of the enterprise, namely socioeconomic and political stability in the country, tax, credit and investment policy of the state, development of stock and insurance markets, the level of real incomes, demographic trends, etc. Among the internal factors are 
the volume and structure of the assets of the enterprise and, importantly, the value and structure of the sources of their financing, the quality of management of both assets and capital, the ability to generate the required financial result and others. These factors can be taken into account on the basis of a comprehensive assessment of the financial position, professional interpretation of its results and timely implementation of appropriate measures to strengthen it, which will ultimately contribute to improving business efficiency and expand the opportunity for enterprise development.

The prospect of further research is the question of the right choice of tools and approaches for assessing the financial condition of an enterprise or agricultural sector.

Література:

1. Базілінська О.Я. Фінансовий аналіз: теорія та практика. К.: Центр учбової літератури, 2011. 328 с.

2. Безбородова Т. В. Удосконалення механізму управління фрінансовими ресурсами підприємств // Держава та регіони. 2016. № 5. С. 21-23.

3. Вишневська О.М. Ресурсний потенціал аграрного сектора економіки України: соціально-економічні та екологічні аспекти: монографія. Миколаїв: Дизайн і поліграфрія, 2014. 487 с.

4. Голубєва Т.С., Колос І.В. Методологічні підходи до оцінки ефективності діяльності підприємства // Актуальні проблеми економіки. 2016. № 5. С. 66-71.

5. Демчук Н.І., Халатур С.М., Хідірян М.О. Теоретичні основи аналізу фрінансового стану сільськогосподарських підприємств. Економіка та суспільство. 2017, № 9, С. 396-400.

6. Державний сайт статистики України. URL: http:/ /www.ukrstat.gov.ua/

7. Hudym K., Khalatur S. (2016). Systematisation and analysis of MNCs' models of conduct for entering the national agrarian markets. Економічний часопис-XXI, 56, pp. $34-37$.

8. Khalatur S. Mechanism of adaptation of agroindustrial complex of Ukraine in the conditions of global food problem. Visnyk Dnipropetrovs' koho derzhavnoho ahrarno-ekonomichnoho universytetu. 2015, № 1, pp. 114-116.

9. Khalatur S.M. (2017). Innovative doctrine development of agriculture growth of Ukraine. Технологический аудит и резервы производства. Vol. 4, 5 (36), pp. 19-26.

References:

1. Basilinskaya, O.Ya. (2011), Finansovyj analiz: teoriia ta praktyka [Financial Analysis: Theory and Practice], Center for Educational Literature, Kyiv, Ukraine.

2. Bezborodova, T.V. (2016), "Improvement of the mechanism of management of financial resources of enterprises", State and Regions, vol. 5, pp. 21-23.

3. Vishnevskaya, O.M. (2014), Resursnyj potentsial ahrarnoho sektora ekonomiky Ukrainy: sotsial'noekonomichni ta ekolohichni aspekty [Resource potential of the agrarian sector of the Ukrainian economy: socioeconomic and environmental aspects], Design and Printing, Mykolaiv, Ukraine.

4. Golubeva, T.S. and Kolos, I.V. (2016), "Methodological approaches to the evaluation of the effectiveness of the enterprise", Current problems of economics, vol. 5, pp. $66-71$.

5. Demchuk, N.I. Khalatur, S.M. and Khidiryan, M.O. (2017), "Theoretical bases of analysis of the financial state of agricultural enterprises", Economics and Society, vol. 9, pp. $396-400$.

6. State Statistics Service of Ukraine (2019), available at: http:/ / www.ukrstat.gov.ua/ (Accessed 10 Nov 2019).

7. Hudym, K. and Khalatur, S. (2016), "Systematisation and analysis of MNCs' models of conduct for entering the national agrarian markets", Economic Annals-XXI, vol. 5-6, pp. 34-37.

8. Khalatur, S. (2015), "Mechanism of adaptation of agroindustrial complex of Ukraine in the conditions of global food problem", Visnyk Dnipropetrovs' koho derzhavnoho ahrarno-ekonomichnoho universytetu, vol. 1, pp. 114-116.

9. Khalatur, S.M. (2017), "Innovative doctrine development of agriculture growth of Ukraine", Technological audit and production reserves, vol. 4, 5 (36), pp. 19-26. Стаття надійшла до редакиї 09.12.2019 p.

\section{Науково-практичний журнал} «ЕКОНОМІКА ТА ДЕРЖАВА»

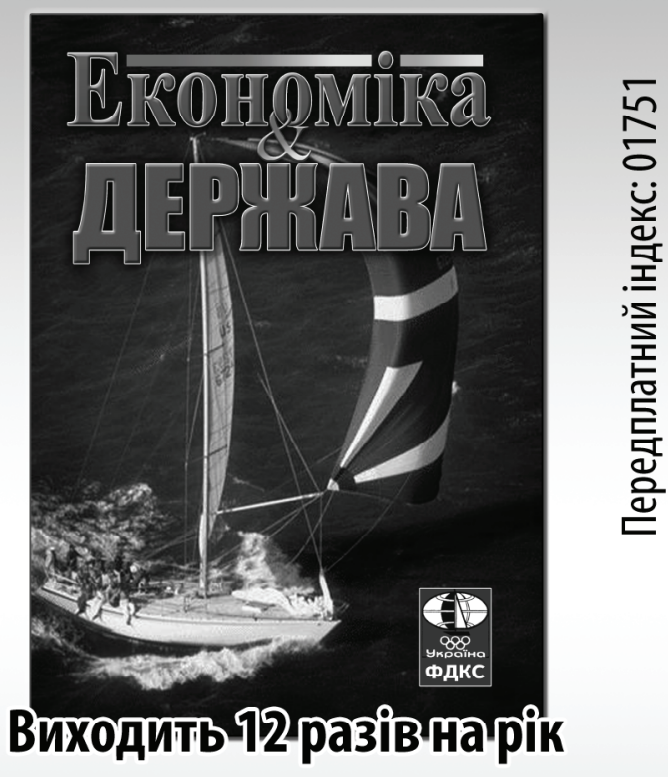

Журнал включено до переліку наукових фахових видань України 3 ЕКОНОМІКИ

www. economy.in.ua

e-mail:economy_2008@ukr.net тел.: (044) 223-26-28 (044) $458-10-73$ 